\title{
National Ignition Facility Environment, Safety, and Health Management Plan
}

National Ignition Facility Project

RECEVED

AUG 221996

OSTI

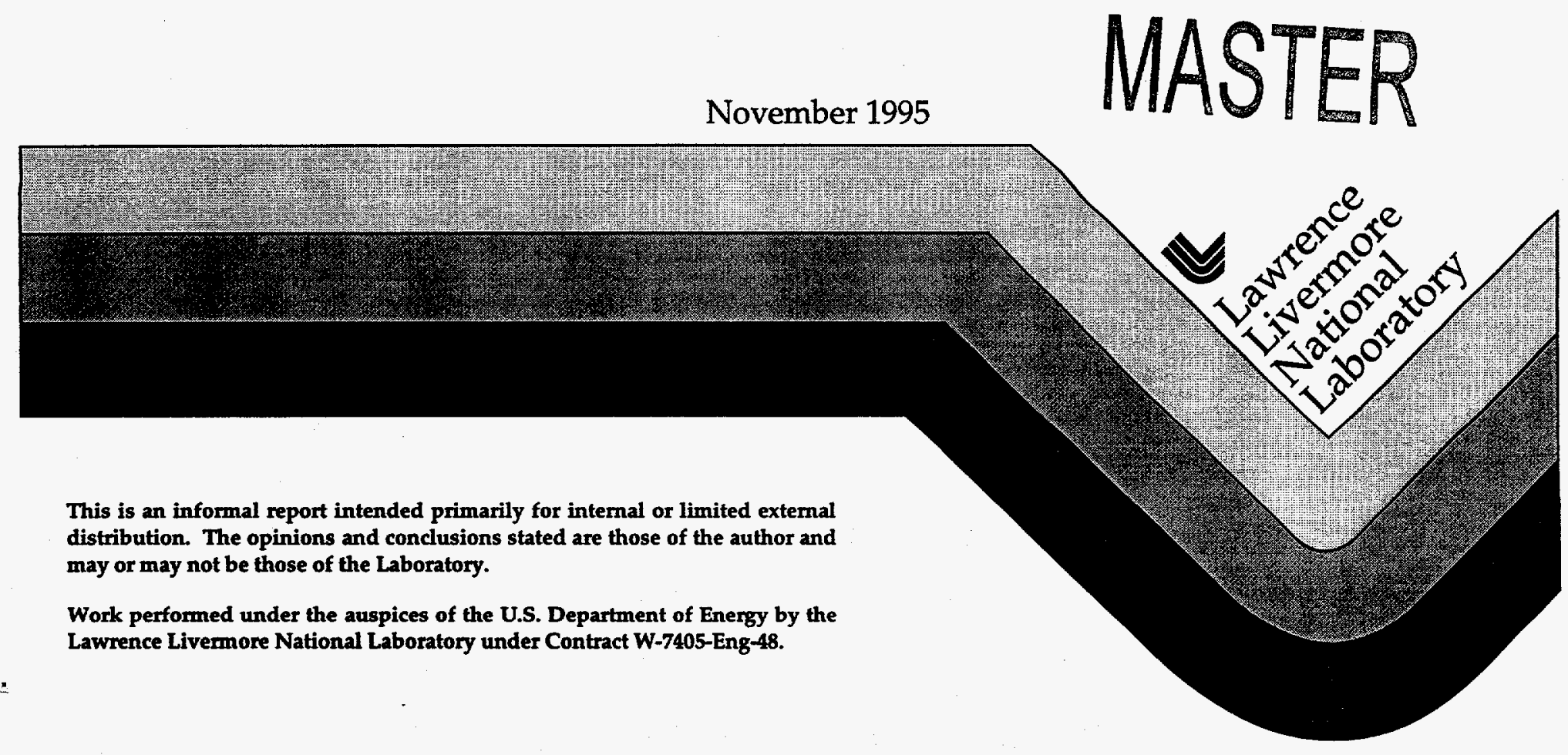




\section{DISCLAIMER}

This document was prepared as an account of work sponsored by an agency of the United States Government. Neither the United States Government nor the University of California nor any of their employees, makes any warranty, express or implied, or assumes any legal liability or responsibility for the accuracy, completeness, or usefulness of any information, apparatus, product, or process disclosed, or represents that its use would not infringe privately owned rights. Reference herein to any specific commercial product, process, or service by trade name, trademark, manufacturer, or otherwise, does not necessarily constitute or imply its endorsement, recommendation, or favoring by the United States Government or the University of California. The views and opinions of authors expressed herein do not necessarily state or reflect those of the United States Government or the University of California, and shall not be used for advertising or product endorsement purposes.

This report has been reproduced directly from the best available copy.

Available to DOE and DOE contractors from the Office of Scientific and Technical Information P.O. Box 62, Oak Ridge, TN 37831

Prices available from (615) 576-8401, FTS 626-8401

Available to the public from the

National Technical Information Service

U.S. Department of Commerce

5285 Port Royal Rd.,

Springfield, VA 22161 


\section{DISCLAIMER}

Portions of this document may be illegible in electronic image products. Images are produced from the best available original document. 

L-20523-1

National Ignition Facility Environment, Safety, and Health Management Plan

Submitted:

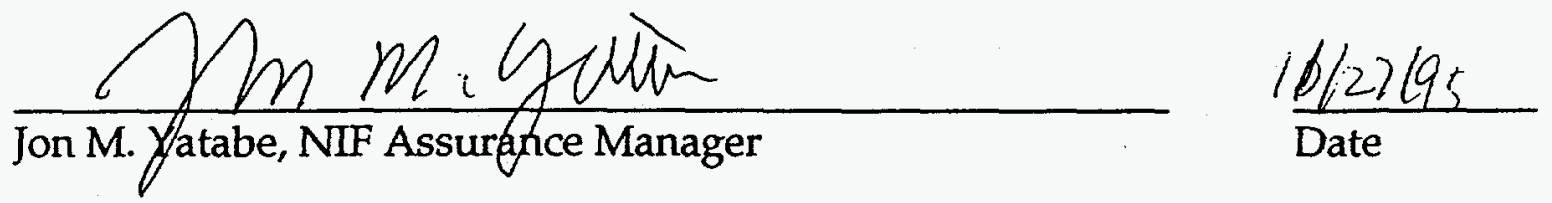

Concurred:

Atty. Sassier

Jeffrey A.Paisner, NIF Laboratory Project Manager

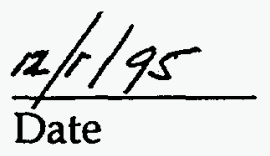

Reviewed:
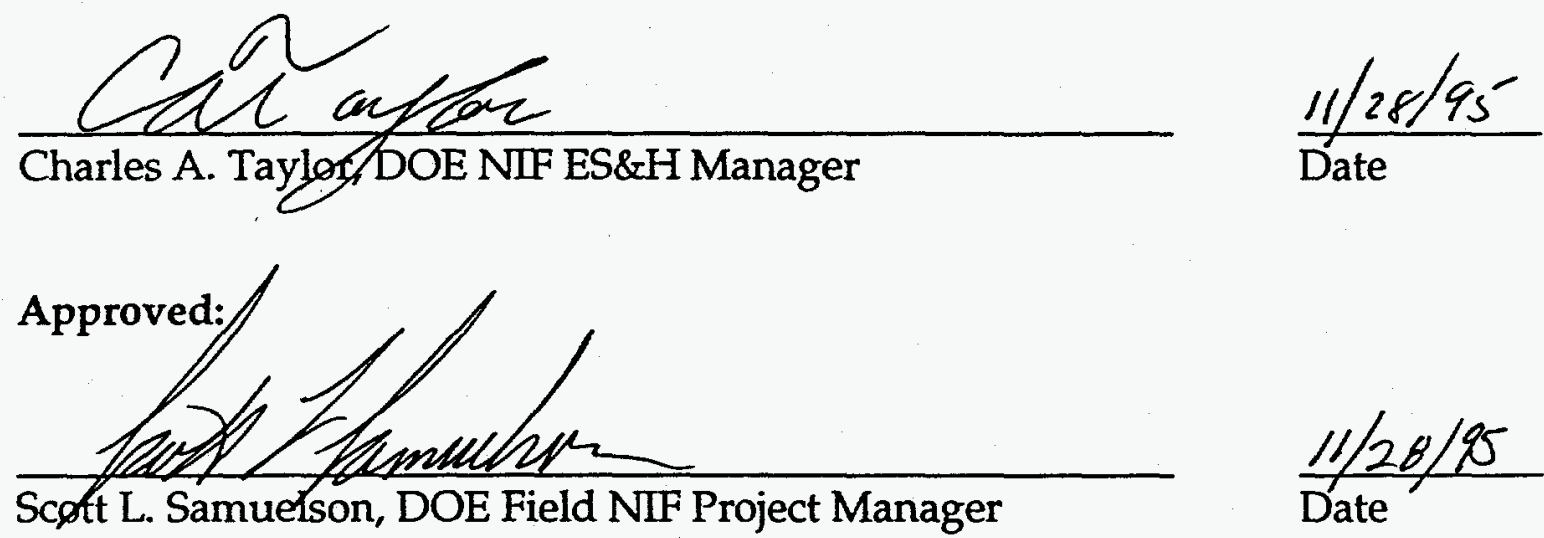

i 


\section{Contents}

1. National Ignition Facility Environment, Safety, and Health Policy ................ I

1.1 Summary ............................................................................................... 1

2. Project ES\&H Responsibilities ...............................................................................

2.1 As Low As Reasonably Achievable (ALARA) Program .......................4

2.2 Radiological Control ................................................................................... 4

2.3 Control of Hazardous Materials ............................................................... 5

2.4 Hazards Evaluation and Safety Analysis ................................................ 5

2.5 Industrial, Construction, and Occupational Safety .................................. 6

2.6 Fire Safety ................................................................................................. 6

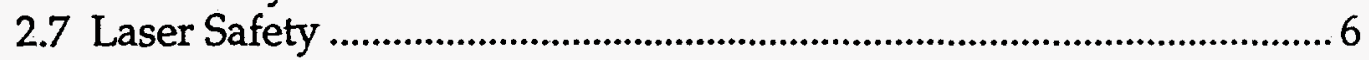

2.8 Emergency Preparedness ............................................................................ 7

2.9 Security ................................................................................................... 7

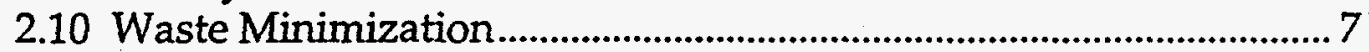

2.11 Waste Management ....................................................................................... 8

2.12 NEPA Determination........................................................................... 9

2.13 Permitting ........................................................................................

2.14 Environmental Monitoring ...................................................................... 10

2.15 Operational Readiness Review (ORR) ................................................... 10

2.16 Quality Assurance (QA) ...................................................................... 10

3. NIF Public Environment and Safety Review Panel............................................. 12

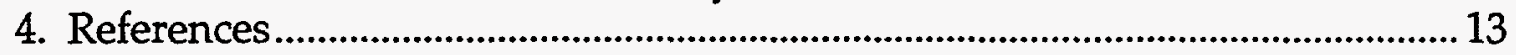




\section{List of Acronyms}

ALARA as low as reasonably achievable (attainable)

ANL

Argonne National Laboratory

CDR

Conceptual Design Report

$\mathrm{CM}$

Construction Manager

DOE

Department of Energy

DOE/OAK Department of Energy Oakland Operations Office

DP

Defense Programs

ES\&H environment, safety, and health

FHA

Fire Hazards Analysis

FSAR

FSP

HWM

ICF

Final Safety Analysis Report

LANL

Facility Safety Procedure

LLNL

LLW

Hazardous Waste Management

inertial confinement fusion

Los Alamos National Laboratory

NEPA

Lawrence Livermore National Laboratory

NESHAP

low-level (radioactive) waste

National Environmental Policy Act

NIF

NTS

National Emission Standards for Hazardous Air Pollution

ORR

National Ignition Facility

Nevada Test Site

OSHA

Operational Readiness Review

OSR

OTP

Occupational Safety and Health Administration

PEIS

PHA

Operational Safety Requirement

Operational Test Procedure

Programmatic Environmental Impact Statement for Stockpile Stewardship and Management

PSA Project Specific Analysis

PSAR Preliminary Safety Analysis Report

QAPP Quality Assurance Program Plan

RCRA Resource Conservation and Recovery Act

SAR Safety Analysis Report

SNL-NM Sandia National Laboratories-New Mexico

UR/LLE University of Rochester Laboratory for Laser Energetics

WAA waste accumulation area 


\section{National Ignition Facility Environment, Safety, and Health Policy}

The National Ignition Facility (NIF) Project, as a Department of Energy (DOE) Strategic Initiative, will be designed, constructed, and operated in a manner that will ensure the protection of the health and safety of the public, operating personnel, and the environment.

The policy of the NIF Project is to take all reasonable precautions in the performance of its work to protect the health and safety of employees and members of the public and to minimize potential risk to the environment. The NIF Project will comply with all applicable safety and environmental regulations of the DOE, federal, state, and local governments. The NIF facilities and equipment will be designed to assure protection of the workers, public, and the environment. The NIF Project Assurance Team will review and evaluate the design (e.g., the Safety Analysis Report, or SAR) to verify that the design meets the environment, safety, and health (ES\&H) requirements. The Project will adhere to generally recognized standards of performance in the areas of occupational health, laser safety, radiological protection, industrial safety, fire safety, environmental protection, and quality assurance (QA). A graded approach will be used to ensure effective compliance to the applicable ES\&H requirements.

Considerations of ES\&H are an integral part of the NIF Project and will be incorporated into all Project plans and activities. The master plan will be this NIF ESEH Management Plan. This plan will be in effect for the duration of the project, which ends with the completion of the Operational Readiness Review (ORR) and the DOE Critical Decision 4, Approval to Operate. The ESEH Management Plan will be implemented through procedures included in the Project Control Manual. This ES\&H Management Plan will be submitted by the Laboratory Project Manager to the DOE Field NIF Project Manager for approval. Once approved, this Plan will be a controlled NIF Project document throughout its duration.

\subsection{Summary}

The ES\&H Management Plan describes all of the environmental, safety, and health evaluations and reviews that must be carried out in support of the implementation of the NIF Project. It describes the policy, organizational responsibilities and interfaces, activities, and ES\&H documents that will be prepared by the Laboratory Project Office for the DOE. The only activity not described is the preparation of the NIF Project Specific Assessment (PSA), which is to be incorporated into the Programmatic Environmental Impact Statement for Stockpile Stewardship and Management (PEIS). This PSA is being prepared by Argonne National Laboratory (ANL) with input from the Laboratory participants. As the independent NEPA document preparer, ANL is directly contracted by the DOE, and its deliverables and schedule are agreed to separately with DOE/OAK. 
To carry out the DOE policy on ES\&H, DOE/OAK has assigned to the DOE Field NIF Project Manager overall ES\&H responsibility. The DOE Field NIF Project Manager has delegated the oversight responsibility to the DOE NIF ES\&H Manager, who in turn is directly responsible for the preparation of the NIF PSA through ANL supported by input from the participating Laboratories; for the Public outreach in the ES\&H areas for NIF; and for oversight and interface with the Laboratory Project Assurance Manager, who is responsible for the implementation of the ES\&H policy.

The individual activities that are covered in this plan are described in Section 2 and encompass 15 ES\&H areas ranging from the ALARA program to the ORR. These activities will result in the following documents:

- NIF ALARA Program Description.

- Preliminary Safety Analysis Report (PSAR).

- Final Safety Analysis Report (FSAR).

- Preliminary Hazards Analysis (PHA).

- Operational Safety Requirements (OSRs).

- Facility Safety Procedures (FSPs).

- Construction Safety Plan.

- Operating Procedures (radiological, laser safety, etc.).

- Fire Hazards Analysis (FHA).

- Emergency Preparedness (section).

- Security Plan.

- Waste Management Plan.

- National Environmental Policy Act (NEPA) document, the NIF Project Specific Analysis (PSA), prepared by ANL.

- Environmental Permits.

- Operational Readiness Review report (ORR).

- Quality Assurance Program Plan (QAPP).

- Subtier quality assurance plans. 


\section{Project ES\&H Responsibilities}

Overall Project responsibility for ES\&H has been assigned to the DOE Field NIF Project Manager, who has delegated the responsibility for the oversight of NIF ES\&H to the DOE NIF ES\&H Manager. The DOE NIF ES\&H Manager uses the matrix DOE/ OAK ES\&H staff to provide the necessary support for review of ES\&H documents and oversight of NIF construction. The ES\&H requirements derive from DOE Orders and the implementation of DOE/OAK Management Directives, plus state, federal, and local regulations. The DOE NIF ES\&H Manager interfaces with the NIF Project Assurance Manager, who is responsible in the Laboratory Project Office for implementing the ES\&H policies. The NIF Project Assurance Manager coordinates assurance professionals at each participating laboratory in the national project (LANL, SNL, UR/LLE, LLNL) to develop the plans, evaluations, and implementation of the ES\&H activities. The DOE NIF ES\&H Manager is also responsible for public outreach in ES\&H areas. This responsibility, supported by the Laboratories, is described in Chapter 3.

The key ES\&H activities, that are included within the NIF ES\&H Program are listed below and are discussed in the following sections. A graded approach will be used throughout the NIF ES\&H Program.

1. As low as reasonably achievable/attainable (ALARA) program.

2. Radiological control.

3. Control of hazardous materials.

4. Hazards and safety analysis (including PHA, PSAR, and FSAR).

5. Industrial, construction, and occupational safety.

6. Fire safety.

7. Laser safety.

8. Emergency preparedness.

9. Security.

10. Waste minimization.

11. Waste Management

12. NEPA determination.

13. Permitting.

14. Environmental monitoring.

15. ORR.

16. QA.

The following sections describe these activities. 


\subsection{As Low As Reasonably Achievable (ALARA) Program}

The NIF ALARA program is required by 10 CFR 835 to be a multifaceted program carried out by the operational organization supported by the assurance and engineering staff. The ALARA training program includes training programs, design, health physics procedures, environmental monitoring, and emergency preparedness.

The key ALARA goal is to maintain worker doses at $1 / 10$ of the DOE annual limits. The radiation protection assessment, which can be found in the NIF Conceptual Design Report (CDR) 1 , describes the features of the conceptual design that implement the ALARA program and protect the workers and the public (e.g., shielding, area monitoring, dosimetry). The program includes:

- Dose-reduction methodologies.

- Design basis dose calculations (e.g., time-motion studies) to achieve the 1/10annual goal.

- In situ measurement and verification.

- Administrative procedures.

- Review and audit of the program by the host site laser assurance office.

- Waste minimization initiatives (low-level radioactive and mixed waste).

- Management commitment.

- Records.

\subsection{Radiological Control}

The radiological adequacy of designs (e.g., confinement, shielding) shall be reviewed. The initial review was performed in the NIF Radiological Evaluation. ${ }^{2}$ The added activities include:

- Time-motion studies to accurately evaluate worker dose levels for the proposed operations.

- Documentation of how radiological safety controls have been incorporated into the design with review and control during design review.

- Occupational radiation monitoring systems, e.g., area monitors, dosimetry, National Emission Standards for Hazardous Air Pollution (NESHAP) compliance.

- Active participation of a trained and qualified senior radiation analyst in all hazards evaluation, including input to the PSAR and FSAR. 
- Input to NIF training requirements and operations and maintenance procedures from the radiation protection staff.

- Review of the NIF conceptual, Title I and Title II designs by experienced radiological engineers.

\subsection{Control of Hazardous Materials}

The NIF Project will meet the requirements of the Resource Conservation and Recovery Act (RCRA 40CFR260-268 and 270), state, and local requirements as they relate to the monitoring and control of nonradioactive hazardous substances and mixed wastes.

The NIF Project initially considered hazardous materials and potential accident impacts in the PHA. These evaluations led to a NIF hazard category of low hazard in accordance with the DOE standards. This hazards categorization will be reevaluated in the NIF PSAR and FSAR.

Industrial safety design features will be provided for the safe handling, use, and storage (e.g., ventilated enclosures) of hazardous and toxic materials. The PSAR, and later FSAR, will provide a basis for management judgment regarding the adequacy of the safety aspects of the design. The safety analysis and review process assures that (1) the health and safety of the public and employees are protected and (2) the environment is protected from hazardous and toxic materials.

\subsection{Hazards Evaluation and Safety Analysis}

The hazards evaluation and safety analysis is a continuous process from the beginning of conceptual design through the final ORR. The key documents are the PHA, PSAR, FSAR with OSRs, FSPs, and Operational Safety Procedures (OSPs). The PHA has already been approved by DOE/OAK and the NIF has been established as a radiological, non-nuclear, low-hazard facility. This designation establishes the requirements for the PSAR and FSAR. The DOE safety orders require that the PSAR be prepared and approved prior to NIF construction. (The separate construction safety plan is described in Section 2.5 below.)

The FSAR will contain a current and complete description of the NIF and proposed operation. The FSAR will contain the OSRs, which represent safe operating limits, limiting conditions for operation, design, surveillance, limiting control settings, and administrative controls to ensure safe operation.

The DOE NIF ES\&H Manager uses the matrix DOE/OAK ES\&H staff and support services contractor to review and then concur with these safety documents prepared by 
the Laboratory Project Office. In this concurrence, the hazard categorization of the facility is reviewed and updated if necessary.

\subsection{Industrial, Construction, and Occupational Safety}

The industrial hygiene and occupational safety program will be planned (in accordance with the Occupational Safety and Health Administration [OSHA] standards) early in the design phase so that the Construction Safety Plan can be prepared by the Construction Manager (CM) prior to $\mathrm{CD} 3$, approval to begin construction. The Construction Safety Plan will cover all aspects of the NIF construction under the responsibility of the CM. The start-up and operational industrial and life safety plans will be under the NIF Operations organization. The program will use professionally trained and qualified staff and resources with authority to implement the NIF industrial hygiene and safety program. This will include formal procedures, reporting levels for safety personnel to ensure that they have a direct line to upper management, effective quality assurance and control programs, and a formal internal audit program.

\subsection{Fire Safety}

DOE Order $5480.7 \mathrm{~A}^{3}$ provides the fire safety requirements for the NIF. Design features of the NIF will limit combustible loading and will provide for fire alarm, fire suppression, and fire separation (e.g., rated fire barriers). Professional fire-protection engineers will be involved in the NIF design reviews to ensure that fire-protection and life-safety codes and criteria are met. They will follow facility construction and start-up to ensure that the design requirements are properly carried out. An independent Fire Hazards Analysis (FHA) will be prepared to evaluate the conceptual design fireprotection systems. This FHA will be incorporated into the PSAR. An updated FHA will evaluate the final design and be included in the FSAR.

\subsection{Laser Safety}

A NIF Laser Safety Officer will be appointed (or the duties of the current LLNL Laser Safety Officer will be extended) to ensure that the requirements of ANSI-Z-136.14 are carried out. This officer will perform the following functions: (1) Make sure that the laser safety standards, documentation, and training progress are implemented;

(2) review laser designs and operating and maintenance procedures to ensure that safety requirements are properly incorporated; (3) provide input to and review all hazards evaluations. 


\subsection{Emergency Preparedness}

The NIF specific requirements will be added to the host site's emergency preparedness program. This program will be documented to include responsibilities, specific responses, interface to other site facilities, and integration with the host site's emergency preparedness program.

\subsection{Security}

The DOE 5632 and 470 series of orders establishes policies and requirements for the physical protection of DOE property and security interests. Requirements include those for physical protection of classified equipment signals and data, DOE property and unclassified facilities, protective program operations, and personnel security, including issuance, control, and use of badges, passes, and credentials. The NIF has not been designated a vital facility by the $\mathrm{DOE}^{5}$. In spite of recent declassification of inertial confinement fusion information, the protection of classified data and equipment plays the dominant role in the overall physical protection program. The NIF Security Plan will be prepared to describe the requirements and implementation. The final NIF Security Plan will be approved prior to the ORR.

\subsection{Waste Minimization}

The NIF operation will generate hazardous, low-level radioactive and mixed (lowlevel radioactive and hazardous) waste. The applicable DOE orders 6 all refer to requirements for waste minimization as an integral part of the NIF waste management program. This is a priority activity and will be included in the NIF PSA in the PEIS for Stockpile Stewardship and Management. The DOE guidelines are:

- Establish a waste minimization program for minimizing the volume and toxicity of all hazardous and radioactive wastes generated.

- Minimize waste in new process design and operation.

- Avoid use of hazardous materials with low-level radioactive materials (e.g., tritiated waste) to minimize mixed waste.

- Recycle and reuse material that would be disposed of as hazardous or mixed waste.

- Minimize power consumption to reduce generation of wastes associated with electrical energy.

- Minimize generation of nonhazardous waste and construction debris.

- Replace hazardous cleaners (e.g., optics cleaners) and solvents with nonhazardous material when possible. 


\subsection{Waste Management}

\subsubsection{Construction Phase}

The construction of the NIF involves only nonhazardous waste generation. The waste would be handled under conventional construction regulations where site capacity is adequate, or arrangements will be made with offsite waste disposal facilities to handle these waste streams.

\subsubsection{Operation Phase}

The operation of the NIF generates quantities of low-level radioactive waste (LLW), hazardous waste, and mixed (radiological and hazardous) wastes. Technologies that are employed to minimize wastes are discussed in Section 2.10. The treatment and disposition of the hazardous and nonhazardous waste streams are discussed below.

Low-Level Waste. The solid LLW processed during NIF operations would be disposed of at the Nevada Test Site (NTS). The Nova laser presently generates waste streams that are similar to those that would be produced by the NIF and are currently approved for disposal at NTS.

Mixed Waste. Solid mixed wastes would be sent to an appropriately licensed commercial mixed waste disposal site. Livermore Hazardous Waste Management (HWM) presently has a contract with a commercial handler for disposal of certain mixed waste streams which meet the waste acceptance criteria, and this agreement would be extended to include NIF mixed wastes.

If an acceptable mixed waste stream contains only "characteristic" hazards and it passes the appropriate leaching test after stabilization, the waste would be approved for shipment to NTS. However, if the mixed waste stream contains a "listed" hazard, it would be shipped to an approved commercial handler after it has been stabilized and meets land disposal requirements. The mixed aqueous waste from cleaning the debris shield would be neutralized, stabilized, and shipped to NTS for disposal as an approved waste stream. If this waste is found to be contaminated with "listed" solvents not approved for NTS disposal, the stabilized waste would be sent to a commercial handler instead.

Hazardous Waste. The NIF candidate sites presently dispose of large quantities of hazardous waste by a well established system using onsite consolidation and shipment to commercial handlers. Capacitors and general chemicals are currently disposed of under this procedure. Based on this approach, the NIF solid hazardous wastes would be shipped to an approved commercial RCRA treatment, storage, and disposal facility.

Nonhazardous Waste. A treatment facility with a capacity of $49,160 \mathrm{~L} / \mathrm{d}$ $(12,987 \mathrm{gal} / \mathrm{d})$ would be provided for the handling of industrial wastewater. Storm drains would be available in the NIF site with a capacity adequate for a design basis flood level local rainfall based on a low-hazard-use building per DOE STD 1020-94, 
Section 6.1.3. Nonhazardous solid waste generation at the NIF site is estimated to be $6,000 \mathrm{~m}^{3} / \mathrm{yr}\left(7,848 \mathrm{yd}^{3} / \mathrm{yr}\right)$. This solid waste will be handled following general regulations.

\subsection{NEPA Determination}

The NIF will comply with applicable federal and DOE environmental protection laws and guidelines. To fulfill DOE policies and goals, the NIF operations must protect the environment and the safety and health of workers and the public.

The DOE NEPA strategy is to prepare a NIF PSA as part of the PEIS. The PSA covers the design, construction, and operation of the NIF at the preferred and alternative sites; this will also address the no-action alternative.

The NIF Project Office will provide all of the input data to the independent NEPA document preparer, ANL. Site input data will be provided by Los Alamos National Laboratory (LANL), Lawrence Livermore National Laboratory (LLNL), Nevada Test Site (NTS), and Sandia National Laboratories-New Mexico (SNL-NM). The responsibilities of the sites are to (1) provide NIF construction site locations, (2) provide affected environment discussions, (3) provide radiological source terms, effluents, waste generation, and hazardous material inventories (LLNL only), and (4) review the document for factual accuracy.

The NIF PSA will be a part of, and have the same schedule as, the PEIS for Stockpile Stewardship and Management. NIF public meetings will be sessions in the Stockpile Stewardship meetings. All comments on the NIF will be resolved in the NIF section of the Implementation Plan and the PSA portion of the PEIS. The NIF PSA will contain detailed analyses of the environmental impact of construction and operation of the NIF at the preferred and alternative sites. The PEIS Record of Decision will include the NIF site selection, construction, and operation.

\subsection{Permitting}

Once the NEPA determination is complete and the preferred site validated, the NIF Laboratory Project Office will support the DOE in applying for the required federal, state, and local environmental permits. In many cases, this will consist of adding NIF to the host site permits (e.g., NESHAP). RCRA and/or environmental permits for construction will be identified well before construction. Permits for a 90-day hazardous waste storage waste accumulation area (WAA) will be requested if necessary. 


\subsection{Environmental Monitoring}

The NIF Laboratory Project Office, working with the host site, will develop a program of environmental monitoring to establish preoperational site environmental baselines (e.g., baseline prior to NIF start-up and operation). This will be done at the host site after the NEPA determination is completed. Operational monitoring will be part of the host site environmental monitoring system.

\subsection{Operational Readiness Review (ORR)}

The ORR is the last step in the Project leading to CD4, approval to operate. The ORR will review the results of the start-up tests, FSAR, final security plan, environmental permits and monitoring, and operational and maintenance procedures. The review will be conducted by the Laboratory Project Office with oversight by a DOE/OAK team. Planning for the ORR will begin during the final equipment installation and facility start-up phase.

\subsection{Quality Assurance (QA)}

The NIF Project QA Program Plan (QAPP), its referenced design requirement documents, and implementing procedures define the QA program for the NIF Project. This program implements the requirements of the DOE Orders applicable to this DOE strategic system.

The NIF QAPP is consistent with the principles governing QA activities as expressed in the LLNL QA Program Plan. ${ }^{7}$ Furthermore, this QAPP is consistent with the graded and risk-based approach to the application of QA activities of the Laser Programs Directorate Quality Assurance Plan. ${ }^{8}$ It is the policy of the NIF Project to regard risk as the primary consideration in determining the levels of QA activities to be applied to each Project activity or element.

A critical aspect of implementation of the QAPP is the assignment of quality levels. Four quality levels $(0,1,2$, and 3$)$ exist within the Project. The degree and amount of formal documentation required by Level 0 is the highest. Other levels require less. The quality level assigned is determined by assessing the potential consequences in the event of Project activity or element failure. The potential consequences are based on the event's impact on the following items:

1. The environment, public health, and safety.

2. Worker safety.

3. Technical performance.

4. Project budget. 


\section{Schedule.}

A Project activity or element whose potential failure includes consequences to the environment, public health, and safety is a quality Level 0 or 1 item. The consequence thresholds that define quality levels are described in QA implementation procedures contained in the Project Control Manual. 9 


\section{NIF Public Environment and Safety Review Panel}

The DOE NIF ES\&H Manager is responsible for the interaction with the public on NIF ES\&H issues. The DOE NIF ES\&H Manager will accomplish this by involvement in the NEPA public meetings and Dellums public meetings and by sponsoring a public Environment and Safety Review Panel, which would meet periodically to review NIF safety and environmental analyses (e.g., waste minimization initiatives).

The purpose of the public Environment and Safety Review Panel would be to surface concerns, share information, and help assure that stakeholders' input is provided to the DOE and Laboratory NIF Project Offices. The DOE NIF ES\&H Manager is responsible for developing a public outreach plan and charter for the Review Panel, acting as the DOE lead for the Review Panel, and coordinating all input from the Review Panel. The DOE NIF ES\&H Manager will coordinate all meetings and assure that a timely response is provided to all concerns and requests from the Review Panel.

The DOE NIF ES\&H Manager is responsible for all NEPA interactions for the NIF. These interactions include management of scoping meetings and public hearings on the draft and final NIF portions of the PEIS. 


\section{References}

1. National Ignition Facility Conceptual Design Report, UCRL-PROP-117093 Vols. 1-5, Lawrence Livermore National Laboratory.

2. UCRL-LR-11588, 1993, Lawrence Livermore National Laboratory.

3. U.S. Department of Energy, Order 5480.7A.

4. ANSI-Z-136.1

5. National Ignition Facility Conceptual Design Report UCRL-PROP-117093 Appendix A.

6. U.S. Department of Energy, Orders 5820.2A, 5400.3, and 5400.6.

7. LLNL Quality Assurance Plan, M-078, internal document, Lawrence Livermore National Laboratory.

8. Laser Programs Directorate Quality Assurance Plan (DQAP), L-18724-1, Lawrence Livermore National Laboratory, March 1995.

9. Project Control Manual, L-16552-1, internal document, Lawrence Livermore National Laboratory. 
